\title{
Zwiększanie przez zespół kruchości częstości występowania powikłań u pacjentów poddawanych zabiegom kardiologii inwazyjnej i operacjom kardiochirurgicznym
}

\author{
Frailty syndrome increases frequency of complications in patients \\ undergoing invasive cardiology procedures and open-heart surgeries
}

\author{
Magda Sobczyńska, Renata Główczyńska, Grzegorz Opolski
}

I Katedra i Klinika Kardiologii Warszawskiego Uniwersytetu Medycznego

\section{Streszczenie}

Zespół kruchości (FS) jest powszechnym problemem u osób w podeszłym wieku silnie wpływającym na gorsze rokowanie pacjentów. Mimo coraz większego zainteresowania brakuje wystandaryzowanych metod pozwalających na identyfikację osób z tym zespołem. Choroby układu sercowo-naczyniowego są jednym z dominujących problemów pacjentów w starszym wieku. Dzięki dynamicznemu rozwojowi medycyny niejednokrotnie największe korzyści terapeutyczne u chorych powyżej 65. roku życia można osiągnąć za pomocą zabiegów kardiologii inwazyjnej i kardiochirurgii. Warunkiem takiego postępowania jest odpowiednia stratyfikacja ryzyka związanego z procedurą inwazyjną. Podstawą większości skal stosowanych w kardiologii jest wiek chronologiczny chorego. Diagnostyka w kierunku FS umożliwi określenie wieku biologicznego pacjenta, dlatego stanowi ona cenne uzupełnienie powszechnie stosowanych metod oceny ryzyka zabiegów inwazyjnych u chorych w podeszłym wieku.

W pracy przedstawiono definicję, najczęściej stosowane narzędzia do rozpoznawania FS oraz wnioski z wybranych badań nad kruchością u pacjentów poddawanych zabiegom kardiologii inwazyjnej i operacjom kardiochirurgicznym.

Słowa kluczowe: zespół kruchości, podeszły wiek, choroby układu sercowo-naczyniowego, zabiegi kardiologii inwazyjnej, operacje kardiochirurgiczne

Folia Cardiologica 2017; 12, 6: 557-564

\section{Wstęp}

Wraz z rozwojem cywilizacji populacja osób starszych dynamicznie się powiększa. Wpływ na tę sytuację ma nie tylko poprawa statusu socjoekonomicznego, ale przede wszystkim rozwój medycyny i coraz większa dostępność do usług medycznych.

Autorzy dotychczasowych wytycznych postępowania w chorobach układu sercowo-naczyniowego dość często opierali się na badaniach populacji osób młodszych. Tymczasem pacjenci w podeszłym wieku często są obciążeni licznymi chorobami wewnętrznymi. Ponadto, w odróżnieniu od populacji młodszej, seniorów (szczególnie w okresie późnej starości) dotykają takie problemy, jak pogorszenie mobilności, funkcji poznawczych, niedożywienie, trudności w samodzielnym funkcjonowaniu.

Choroby układu sercowo-naczyniowego są jednym z dominujących problemów starszych pacjentów. Dzięki

Adres do korespondencji: dr n. med. Renata Główczyńska, I Katedra i Klinika Kardiologii, Warszawski Uniwersytet Medyczny, Centralny Szpital Kliniczny, ul. Banacha 1a, 02-097 Warszawa, e-mail: renata.glowczynska@wum.edu.pl 
dynamicznemu rozwojowi medycyny zabiegi kardiologii inwazyjnej i kardiochirurgii niejednokrotnie są możliwe także u osób w podeszłym wieku. Konieczne jest jednak odpowiednie wyważenie bilansu między korzyściami płynącymi z takiego postępowania a ryzykiem powikłań leczenia.

W ostatnich latach coraz częściej w publikacjach medycznych pojawia się pojęcie kruchości. Pozwala ono, wśród osób w podobnym wieku chronologicznym, wyodrębnić grupę pacjentów bardziej obciążonych. Dotychczas stosowane skale oceny ryzyka na ogół nie obejmowały takich czynników, jak pogorszenie funkcji poznawczych, zaburzenia równowagi, trudności w samodzielnym funkcjonowaniu itp. Dysfunkcje te przekładały się na większą liczbę powikłań leczenia, dłuższy okres opieki wewnątrzszpitalnej, przedłużenie rehabilitacji poszpitalnej, a przede wszystkim gorszą jakość życia chorego. Rozpoznanie zespołu kruchości (FS, frailty syndrome) wiąże się z bardziej indywidualnym podejściem do chorego i koniecznością wdrożenia leczenia wielodyscyplinarnego, obejmującego opiekę geriatry, rehabilitanta czy psychiatry.

\section{Kruchość - definicja, kryteria rozpoznania i metody diagnostyczne}

Zespół kruchości (inaczej: słabości, wyczerpania rezerw) jest definiowany jako fizjologiczny proces obniżenia rezerw i odporności na czynniki stresogenne związany z pogorszeniem się funkcji wielu układów [1]. Do objawów FS należą: sarkopenia, czyli utrata masy mięśniowej (obwód łydki w połowie jej wysokości < $31 \mathrm{~cm}$ ), zmniejszenie masy ciała i niedożywienie, zmniejszenie siły mięśniowej, pogorszenie tolerancji wysiłku, spowolnienie ruchowe, zaburzenia równowagi, zmniejszona aktywność fizyczna, pogorszenie funkcji poznawczych, zwiększona wrażliwość na działanie czynników stresogennych (ryc. 1).

Najważniejszymi czynnikami sprzyjającymi wystąpieniu FS są zaawansowany wiek, zaburzenia widzenia, obniżony nastrój, upośledzenie funkcji poznawczych, słabość koń- czyn, zaburzenia chodu i równowagi, stosowanie leków uspokajających, współistnienie wielu chorób przewlekłych (przewlekła obturacyjna choroba płuc, cukrzyca, przewlekła choroba nerek, niedokrwistość z niedoboru żelaza, depresja, niewydolność serca [HF, heart failure]) (ryc. 1).

Choć FS dotyka osób w podeszłym wieku, to jego obecność nie jest równoznaczna z procesem starzenia się ani z niepełnosprawnością. U tych chorych częściej występuja nietypowy, cięższy przebieg choroby, nieproporcjonalna utrata niezależności, wczesne i poważne powikłania oraz tylko częściowy powrót do zdrowia po przebytej chorobie.

Dotychczas nie udało się ustalić jednej powszechnie zaakceptowanej metody, która byłaby metodą referencyjną służącą do diagnostyki FS. W praktyce do rozpoznania FS najczęściej stosuje się skalę Fried (tab. 1), zgodnie z którą niezbędne jest stwierdzenie 3 z 5 wymienionych poniżej kryteriów [1, 2], tj. zmniejszenia masy ciała, osłabienia siły mięśniowej, wyczerpania [3], spowolnienia chodu oraz obniżonej aktywności fizycznej [4]. W przypadku obecności 1 lub 2 z powyższych patologii można zidentyfikować osoby obciążone zwiększonym ryzykiem wystąpienia FS przyszłości (pre-frail).

Do innych skal stosowanych w diagnostyce FS należą między innymi [1, 6-8]:

- The Canadian Study of Health and Aging Clinical Frailty Scale (CSHA-FI) (tab. 2);

- Groningen Frailty Indicator (GFI);

- Tilburg Frailty Indicator (TFI) [9];

- Frailty Index (FI) [10];

- Frailty Index based on a Comprehensive Geriatric Assessment (FI CGA);

- Frailty phenotype;

- Edmonton Frail Scale (EFS) [11].

Brak wystandaryzowanych kryteriów pozwalających na identyfikację osób z FS sprawia, że zarówno w praktyce klinicznej, jak i w badaniach naukowych możliwość porównywania wyników otrzymywanych przez różne grupy badaczy i w różnych ośrodkach jest ograniczona.

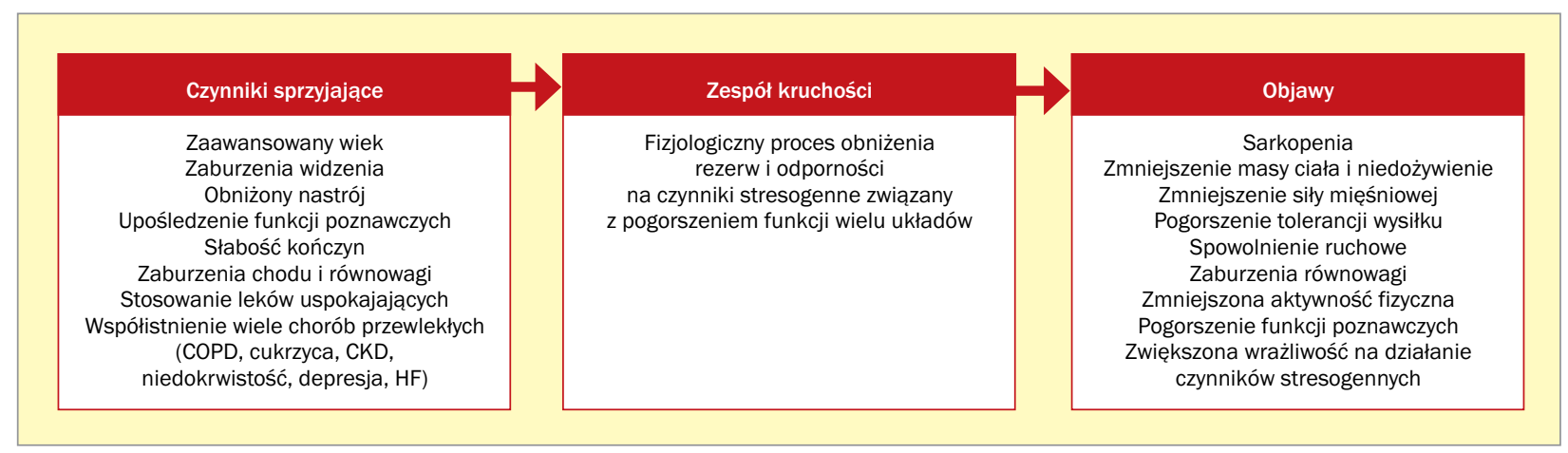

Rycina 1. Czynniki sprzyjające, objawy i definicja zespołu kruchości; COPD (chronic obstructive pulmonary disease) - przewlekła obturacyjna choroba płuc; CKD (chronic kidney disease) - przewlekła choroba nerek; HF (heart failure) - niewydolność serca 
Tabela 1. Skala Fried (opracowano na podstawie $[1,2,5])$ *

\begin{tabular}{|c|c|c|}
\hline Komponent & Definicja & Punkt odcięcia \\
\hline Spowolnienie chodu & $\begin{array}{l}\text { Test chodu na dystansie } 15 \text { stóp ( } 4,6 \text { m), start z po- } \\
\text { zycji stojącej, czas mierzony od postawienia pierw- } \\
\text { szego kroku do przekroczenia linii } 4,6 \text { m pierwszą } \\
\text { stopą; należy wykonać } 3 \text { pomiary i uśrednić wynik }\end{array}$ & $\begin{array}{l}1 \text { pkt, gdy: } \\
\text { - } \quad \text { mężczyzna o wzroście > } 173 \mathrm{~cm} \text {, kobieta } \\
\text { o wzroście > } 159 \mathrm{~cm} \text { osiągną wynik } \geq 6 \mathrm{~s} \\
\text { - } \text { mężczyzna i kobieta o niższym wzroście } \\
\text { osiągną wynik } \geq 7 \mathrm{~s}\end{array}$ \\
\hline Ocena osłabienia & $\begin{array}{l}\text { Ocena siły dłoni za pomocą dynamometru zależnie } \\
\text { od BMI i płci }\end{array}$ & $0-1$ pkt. \\
\hline Chudnięcie & $\begin{array}{l}\text { Ocena niezamierzonego zmniejszenia masy ciała } \\
\text { w ciągu poprzedzających } 12 \text { mies. }\end{array}$ & $\begin{array}{l}1 \text { pkt, gdy zmniejszenie masy ciała } \geq 4,5 \mathrm{~kg} \mathrm{lub} \\
5 \% \text { w ciągu roku }\end{array}$ \\
\hline Wyczerpanie & Oceniane za pomocą skali depresji CES-D [3] & $0-1$ pkt. \\
\hline $\begin{array}{l}\text { Obniżona aktywność } \\
\text { fizyczna }\end{array}$ & $\begin{array}{l}\text { Określona na podstawie kwestionariusza Minnesota } \\
\text { Leisure Time Activity Questionnaire [4] }\end{array}$ & $0-1$ pkt. \\
\hline
\end{tabular}

*Rozpoznanie zespołu kruchości: łączna punktacja $\geq 3$ pkt.; BMI (body mass index) - wskaźnik masy ciała; CES-D - Center for Epidemiologic Studies Depression Scale

Tabela. 2. Skala kruchości według Canadian Study of Health and Aging Clinical Frailty Scale (CSHACFS) (opracowano na podstawie [1, 6-8])

\begin{tabular}{lll}
\hline Kategoria & Charakterystyka \\
1. Wysoka kondycja & $\begin{array}{l}\text { Aktywne, energiczne, dobrze zmotywowane i zdrowe osoby uprawią } \\
\text { i należące do najzdrowszych w swoim przedziale wiekowym }\end{array}$ \\
$\begin{array}{l}\text { Osoby bez aktywnej choroby, ale mniej sprawne od osób z katego } \\
\text { 2. Dobra kondycja }\end{array}$ & $\begin{array}{l}\text { Osoby z leczonymi chorobami wspótistniejącymi (objawy chorób dobr } \\
\text { w porównaniu z osobami z kategorią 4.) }\end{array}$ \\
4. Dobra kondycja & $\begin{array}{l}\text { Osoby, choć niezależne od pomocy innych, to często zgłaszające , } \\
\text { lub objawy istniejących chorób }\end{array}$ \\
5. Łagodna kruchość & Osoby częściowo zależne od pomocy innych w codziennym życiu \\
6. Umiarkowana kruchość & Osoby wymagające częstej pomocy w codziennym życiu \\
7. Poważna kruchość & Osoby całkowicie zależne od pomocy innych lub terminalnie chore
\end{tabular}

\section{Patofizjologia i epidemiologia}

Przyczyn FS do końca nie poznano. Wzrost stężenia markerów zapalnych, zaburzenia krzepnięcia oraz dysregulacja procesów neuroendokrynnych [5, 12] wydają się ściśle związane z powstaniem tego zespołu. Ponadto dochodzi do obniżenia wartości hormonu wzrostu i hormonów płciowych (estrogenu i testosteronu) oraz zaburzeń wydzielania kortykosteroidów [13]. Proces zapalny oraz obniżone stężenie hormonów anabolicznych sprzyjają katabolizmowi, prowadzącemu do utraty masy mięśniowej, spowolnieniu motorycznemu czy stopniowemu pogarszaniu się funkcji poznawczych.

Ocenia się, że w Polsce FS dotyka 6,7\% osób starszych, w tym ponad $30 \%$ osób w wieku $75-80$ lat i $50 \%$ powyżej 80. roku życia. W Stanach Zjednoczonych średnio 9,5\% populacji osób powyżej 65. roku życia to osoby z FS, przy czym odsetek ten wzrasta do 25\% wśród osób powyżej 85. roku życia. W Europie zespół ten występuje średnio u 17\% osób (5,8\% w Szwajcarii, 27\% w Hiszpanii) [14]. Należy dodać, że w populacji osób między 64. a 74. rokiem życia
FS częściej dotyka kobiet niż mężczyzn (8,5\% v. 4,1\%), częściej osób o niższym poziomie wykształcenia i niższym statusie socjoekonomicznym $[1,2]$.

\section{Kruchość u pacjentów z chorobami układu sercowo-naczyniowego}

U chorych w podeszłym wieku najczęstszą grupą schorzeń są choroby układu sercowo-naczyniowego. Równocześnie FS występuje 3-krotnie częściej u osób obciążonych kardiologicznie niż w populacji ogólnej, a ponadto towarzyszą mu większa śmiertelność i większa częstość ponownej hospitalizacji [15-17]. Pacjenci z FS częściej są obciążeni niedokrwienną chorobą serca, HF czy nadciśnieniem tętniczym $[18,19]$. Objawy FS stwierdza się u 30-50\% chorych z HF. W obserwacji rocznej chorych z FS śmiertelność zwiększa się wraz z nasileniem objawów zespołu (może być 2-4-krotnie wyższa), podobnie wzrasta ryzyko ponownej hospitalizacji z powodu zaostrzenia HF [20].

U pacjentów z FS również częściej obserwuje się subkliniczne cechy miażdżycy, takie jak pogrubienie 
kompleksu błony środkowej i wewnętrznej (IMC, intima-media complex) w tętnicach szyjnych wspólnych i wewnętrznych, obniżony wskaźnik kostka-ramię $(\leq 0,8)$, większą masę lewej komory w badaniu echokardiograficznym i większy stopień zmian niedokrwiennych w ośrodkowym układzie nerwowym stwierdzanych w badaniu metodą rezonansu magnetycznego $[15,17]$. Niezależnie od zastosowanej metody oceny FS jego rozpoznanie wiąże się z istotnym pogorszeniem rokowania. Pacjenci starsi, obciążeni wysokim ryzykiem sercowo-naczyniowym moga odnieść większe korzyści z interwencji zabiegowych, ale jest to związane z wyższym ryzykiem powikłań, takich jak krwawienia, udar mózgu/przemijający napad niedokrwienny (TIA, transient ischemic attack), niewydolność oddechowa czy niewydolność nerek.

Wyodrębnienie pacjentów z FS spośród populacji osób w podeszłym wieku jest kluczowe do określenia globalnego ryzyka powikłań, nie tylko sercowo-naczyniowych. W większości skal stosowanych w kardiologii (np. SCORE, Framingham, EuroSCORE, GRACE, HAS-BLED) podstawą jest wiek chronologiczny chorego [21-25]. Jednak wiek biologiczny nie zawsze odpowiada chronologicznemu, co może prowadzić do nieadekwatnej oceny ryzyka powikłań u chorych z FS. Jak udowodnili autorzy przytoczonych poniżej prac, skale oceny kruchości są niejednokrotnie istotnym uzupełnieniem skal powszechnie stosowanych w ocenie ryzyka sercowo-naczyniowego.

\section{Ostre zespoły wieńcowe u osób z FS}

Połowa pacjentów hospitalizowanych z powodu ostrych zespołów wieńcowych (ACS, acute coronary syndrome) ma 75 lat i więcej [26]. Ponadto pacjenci starsi są bardziej podatni na poważne powikłania ACS, powikłania krwotoczne, niewydolność nerek czy incydenty mózgowe [27].

Ekerstad i wsp. [28] opisali grupe 307 chorych w wieku co najmniej 75 lat z rozpoznanym zawałem serca bez uniesienia odcinka ST (NSTEMI, non-ST-elevation myocardial infarction), leczonych w 3 szwedzkich ośrodkach. Na podstawie Clinical Frailty Scale (CFS) u 48,5\% chorych rozpoznano FS, w tym u $24,1 \%$ poważny FS. Pacjenci z FS częściej charakteryzowali się średnim lub wysokim ryzykiem sercowo-naczyniowym niż pozostali (94\% v. $86,1 \%$ na podstawie skali Fast Revascularization during Instability in Coronary artery disease II [FRISCII]). Po miesiącu od włączenia do badania FS wiązał się z częstszym występowaniem pierwszorzędowego punktu końcowego (zgon z jakiejkolwiek przyczyny, poważne krwawienie, udar mózgu/TIA, konieczność dializoterapii; 45,6\% v. $27,2 \%)$, śmiertelności $(15,4 \%$ v. 3,2\%), śmiertelności wewnątrzszpitalnej $(10,1 \%$ v. 1,9\%) oraz przedłużonego czasu hospitalizacji (13,4 dnia v. 7,5 dnia). Chorzy krusi byli rzadziej leczeni na oddziałach kardiologii interwencyjnej i rzadziej wykonywano u nich koronarografię. Spośród pacjentów niepoddawanych koronarografii u 47\% wystąpił co najmniej jeden pierwszorzędowy punkt końcowy, 18\% zmarło w ciągu obserwacji trwającej miesiąc.

W obserwacji krótkoterminowej współistnienie FS okazało się ściśle i niezależnie związane z wyższym ryzykiem poważnych powikłań i zgonu starszych pacjentów z ACS. Autorzy badania podkreślili, że kwestia wykonywania koronarografii i angioplastyki wieńcowej u pacjentów z FS wymaga dalszych prospektywnych badań i oceny stosunku ryzyka do korzyści, jakie mogą odnieść opisywani pacjenci.

\section{Operacje kardiochirurgiczne u osób z FS}

Coraz więcej danych wskazuje na to, że starsi pacjenci mogą skorzystać z operacji kardiochirurgicznych [29]. Najczęściej stosowanymi skalami do oceny ryzyka powikłań kardiochirurgicznych są Society of Thoracic Surgeons (STS) i EuroSCORE. Aby lepiej ocenić ryzyko operacji u pacjentów w podeszłym wieku czy znacznie obciążonych, wprowadzono skalę EuroSCORE II, w której ujęto poważne upośledzenie mobilności wtórne do nieprawidłowości w układzie mięśniowo-szkieletowym czy dysfunkcji neurologicznej.

Lee i wsp. [30] ocenili 3826 chorych, którzy przebyli zabieg kardiochirurgiczny, w tym 4,1\% było obciążonych FS. Słabość definiowano jako nieprawidłowości w codziennej aktywności (wg wskaźnika Katza [ADL, Activities of Daily Living]) lub jako udokumentowaną demencje. Pacjenci z FS byli starsi i częściej były to kobiety, a także cechowało ich wyższe ryzyko poważnych powikłań pooperacyjnych. Słabość okazała się niezależnym od wieku predyktorem śmiertelności wewnątrzszpitalnej (14,7\% v. 4,5\%), ponownego przyjęcia do szpitala, skróconego średniego okresu przeżycia $(29,5 \%$ v. 10,6\%) i wydłużenia okresu opieki pooperacyjnej (48,5\% v. 9,0\%). Według autorów ocena w kierunku FS umożliwia lepsze oszacowanie ryzyka u tych chorych i wyodrębnienie grupy, która najbardziej skorzysta z nowoczesnych, małoinwazyjnych metod terapii.

Sündermann i wsp. [31] zwrócili uwagę, że ryzyko operacji kardiochirurgicznych zwykle jest szacowane za pomocą takich skal, jak EuroSCORE czy STS, w których w ogólnej ocenie ryzyka nie ujęto, tak istotnego u pacjentów z FS, wieku biologicznego. Badaniem objęto 400 pacjentów w wieku co najmniej 74 lat, którzy zostali zakwalifikowani do pomostowania aortalno-wieńcowego (CABG, coronary artery bypass grafting), izolowanej operacji zastawki, przezcewnikowej implantacji zastawki aortalnej (TAVI, transcatheter aortic valve implantation) lub procedury złożonej. Kruchość określano na podstawie kryteriów skal Fried oraz CFS, sprawności fizycznej (subiektywnej oceny słabości, testu równowagi, wstawania z krzesła, wchodzenia po schodach), wyników badań laboratoryjnych i czynnościowych (wartości albumin, kreatyniny, peptydu natriuretycznego typu B [BNP, B-type natriuretic peptide], pierwszosekundowej natężonej objętości wy- 
dechowej $\left[\mathrm{FEV}_{1}\right.$, forced expiratory volume in 1 second]). Pierwszorzędowym punktem końcowym była korelacja obliczonego Fl z 30-dniową śmiertelnością. Na podstawie kompleksowej oceny tylko połowę chorych określono jako nieobciążonych FS, 42,5\% - jako umiarkowanie obciążonych $\mathrm{FS}$, zaś 7,75\% - jako poważnie obciążonych tym zespołem. Średni FI wyniósł 11 (7-15). Wskaźnik ten był wyższy u pacjentów kierowanych na TAVI - średnio wyniósł 12 (7-19). Średnie ryzyko wyliczone na podstawie skal ryzyka operacyjnego przyjęło wartości, odpowiednio, logistic EuroSCORE 8,5\% (5,8-13,9\%), STS score 3,3\% (2,1-5,1\%). Wykazano istotną statystycznie (choć najwyżej umiarkowaną) korelację FS z wynikami w skalach STS i EuroSCORE, co wskazuje na to, że ocena kruchości jest niezbędnym uzupełnieniem powszechnie stosowanych skal. Wskaźnik FS wykazał także istotną korelację stopnia kruchości z 30-dniową śmiertelnością. Analizując 3 grupy pacjentów (niekrusi, umiarkowanie krusi, ciężko krusi) udowodniono, że 30-dniowa śmiertelność jest znacząco wyższa u chorych z ciężkim FS (odpowiednio: 3,6\% v. 7,8\% v. 21,7\%). Obecność FS okazała się niezależnym predyktorem śmiertelności wewnątrzszpitalnej.

Podobne wnioski wykazali Sündermann i wsp. [32], badając grupe 450 chorych kierowanych na elektywny zabieg kardiochirurgiczny (TAVI, CABG, izolowaną operację zastawki). Kruchość mierzono za pomocą Powszechnego Modelu Oceny i FORESCAST (the Frailty predicts death One yeaR after CArdiac Surgery Test). Śmiertelność 30-dniowa wyniosła $6,1 \%$, a roczna $13,3 \%$. Obie skale stanowiły istotne uzupełnienie STS i EuroSCORE, ale w przeciwieństwie do nich nie były oparte na wieku chronologicznym. Wyniki w CAF i FORECAST korelowały z śmiertelnością krótkoi długoteminową.

Afilalo i wsp. [33, 34] udowodnili, że spowolnienie chodu jest niezależnym czynnikiem predykcyjnym śmiertelności u osób starszych kierowanych na operacje kardiochirurgiczne. Do wieloośrodkowego prospektywnego badania włączono pacjentów w wieku co najmniej 70 lat, zakwalifikowanych do CABG czy operacyjnej implantacji/wymiany zastawki. Badanie objęło 131 pacjentów w średnim wieku 75,8 roku, przy czym $34 \%$ stanowiły kobiety. Spowolnienie chodu określano jako czas potrzebny do przejścia $5 \mathrm{~m}$ wynoszący 6 s lub dłuższy. Jako wolno chodzących przed operacją określono 46\% pacjentów. Pierwszorzędowym punktem końcowym była wewnątrzszpitalna śmiertelność pooperacyjna lub duża chorobowość określana na podstawie STS score jako zgon z dowolnej przyczyny i 5 dużych komplikacji (udar mózgu, niewydolność nerek, przedłużona wentylacja mechaniczna, głęboka infekcja rany mostka, konieczność reoperacji). U 23\% pacjentów opisano pierwszorzędowy punkt końcowy w postaci zgonu lub znacznej chorobowości po operacji kardiochirurgicznej. Spowolnienie chodu okazało się niezależnym czynnikiem śmiertelności po skorygowaniu według STS i wiązało się z 2-3-krotnym wzrostem ryzyka śmiertelności/dużej chorobowości.

Prędkość chodu to prosty i efektywny test, który może ułatwić identyfikację starszych chorych z FS, obciążonych zwiększonym ryzykiem śmiertelności/dużej chorobowości po operacjach kardiochirurgicznych. Włączenie testu prędkości chodu do oceny przedoperacyjnej osób starszych pozwoli lepiej wyodrębnić populację obciążoną wyższym ryzykiem poważnych powikłań pooperacyjnych, wymagającą zintensyfikowanej, przedłużonej opieki wewnątrzszpitalnej czy rehabilitacji pooperacyjnej.

\section{Zabieg TAVI u osób z FS}

W ostatnich latach gwałtownie wzrasta liczba zabiegów TAVI wykorzystywanych jako główna metoda leczenia starszych pacjentów obciążonych wysokim ryzykiem operacji klasycznej i objawową ciężką stenozą aortalną. Od 80 do 90\% chorych kierowanych na TAVI to osoby z FS (zgodnie z definicją fenotypu kruchości).

Green i wsp. [35] badali związek między dystansem pokonywanym przez pacjentów w 6-minutowym teście chodu (6MWT, 6-minute walk test) a rokowaniem chorych po TAVI w populacji badania PARTNER (Placement of AoRtic TraNscathetER Valves). Chorych, na podstawie wyniku w 6MWT, zakwalifikowano do 3 grup jako niezdolnych do chodzenia, chodzących wolno (< 128,5 m) albo chodzących szybko (> 128,5 m). Rok po zabiegu ponownie oceniano chorych za pomocą 6MWT. Wśród szybko chodzących pokonany w teście dystans skrócił się do 44-148 m, wśród wolno chodzących wydłużył się do 58-126 m, a u niechodzących - do 66-109 m. Po 30 dniach nie opisano różnicy w zakresie śmiertelności z dowolnej przyczyny, śmiertelności z przyczyn sercowych, udarów mózgu czy powtórnej hospitalizacji. W ciągu 2 lat obserwacji liczba zgonów z dowolnej przyczyny wynosiła, odpowiednio, 42,5\% wśród pacjentów niemogących chodzić, 31,2\% u wolno chodzących i $28,8 \%$ u szybko chodzących (w odniesieniu do zgonów z przyczyn kardiologicznych, odpowiednio, $14,1 \%$ v. 13,0\% v. 11,6\%, oraz niekardiologicznych: $33,1 \%$ v. $20,9 \%$ v. 19,4\%). Podsumowując, autorzy badania podkreślili, że u pacjentów starszych, najbardziej obciążonych wynik 6MWT dodatnio koreluje z przeżyciem długoterminowym. Dodatkowo największą poprawę obserwowano u osób z najgorszymi wynikami 6MWT. Konieczne są dalsze badania w celu wyodrębnienia chorych kruchych, którzy najbardziej skorzystają z TAVI, a przytoczony test chodu jest jedną z najprostszych metod oceny tej grupy pacjentów.

Dwa lata później Green i wsp. [36] ponownie analizowali pacjentów z badania PARTNER pod kątem związku kruchości z gorszym rokowaniem po zabiegu TAVI. Ogółem do analizy włączono 244 chorych, u których wykonano TAVI i których przed zabiegiem oceniono po kątem obecności 
FS. Pierwszorzędowym punktem końcowym był zgon z dowolnej przyczyny po roku obserwacji. Drugorzędowe punkty końcowe stanowiły: zgon z przyczyn sercowych w ciągu 30 dni od zabiegu, powtórna hospitalizacji z powodu stenozy aortalnej albo komplikacji związanych z procedurą, udar mózgu, duże krwawienie, duże powikłanie naczyniowe, konieczność implantacji stymulatora serca, niewydolność nerek wymagająca dializ. Po 30 dniach obserwacji nie stwierdzono różnic pod względem częstości występowania drugorzędowych punktów końcowych w obu badanych grupach, jednak po roku z dowolnej przyczyny zmarło 32,7\% pacjentów z FS oraz jedynie 15,9\% pozostałych chorych. Chorych z FS cechowało wyższe ryzyko zgonu z przyczyn sercowych niż pozostałych badanych (15\% v. 8,4\%). Podobna zależność dotyczyła zgonu z przyczyn niesercowych (9,5\% v. 4,9\%). Kruchość wiązała się z 2,5 razy wyższym ryzykiem zgonu w obserwacji rocznej. Zarówno po 6, jak i po 12 miesiącach w grupie pacjentów z FS obserwowano większą śmiertelność i wyższe ryzyko wystąpienia drugorzędowych punktów końcowych (odpowiednio 41,9\% v. $27,6 \%$ oraz $50 \%$ v. $31,5 \%$ ).

Puls i wsp. [37] badali wpływ FS na wczesną i późną śmiertelność pacjentów poddanych zabiegowi TAVI. Badaniem objęto 300 pacjentów w średnim wieku $82 \pm 5$ lat, spośród których 144 określono jako kruchych (wskaźnik Katza < 6). Wczesna śmiertelność była znacznie wyższa wśród chorych z FS $(5,5 \%$ v. 1,3\% dla śmiertelności okołozabiegowej, $17 \%$ v. 5,8\% dla śmiertelności 30-dniowej i 23\% v. 6,4\% dla całkowitej śmiertelności związanej z procedura). Obliczone na podstawie powszechnie stosowanych skal oceny ryzyka sercowo-naczyniowego 30-dniowe ryzyko zgonu (29\% v. 24\% w EuroSCORE I, 9,5\% v. 7,5\% w EuroSCORE II i 8,8\% v. 5,9\% w STS score) nie uzyskało pełnego odzwierciedlenia w wynikach przebadanej grupy. Kruchość (wskaźnik Katza < 6) zidentyfikowano jako istotny niezależny czynnik śmiertelności (bez względu na przyczynę) w obserwacji 30-dniowej. Równocześnie w dalszej obserwacji (mediana 537 dni) zmarło 56\% pacjentów z FS oraz jedynie $24 \%$ pozostałych. Autorzy zaproponowali, aby ocenę kruchości (m.in. na podstawie wskaźnika Katza) włączyć do oceny ryzyka u pacjentów przed TAVI.

Stortecky i wsp. [38] podkreślają rolę wielodyscyplinarnej oceny geriatrycznej (MGA, Multidimensional Geriatric Assessment) w stratyfikacji ryzyka zgonu, poważnych zdarzeń sercowo-naczyniowych czy mózgowych (MACCE, mortality and major adverse cardiovascular and cerebral events) u osób starszych poddawanych zabiegowi TAVI. Przebadali grupe 100 pacjentów w wieku powyżej 75 lat. Porównali ryzyko szacowane za pomocą skal STS i EuroSCORE z ryzykiem przewidywanym według
MGA. Na podstawie FI u 49\% pacjentów rozpoznano FS. Wyniki oceny 30-dniowej i rocznej śmiertelności z dowolnej przyczyny oraz MACCE według MGA były zbliżone do wyników oceny w STS i EuroSCORE. Ponadto ryzyko wyliczone za pomocą MGA było niezależne od ryzyka obliczonego za pomocą STS czy EuroSCORE. Autorzy podkreślili, że globalną ocenę ryzyka można uściślić, włączając MGA do standardu postępowania u osób starszych przed zabiegiem TAVI. Metody oceny MGA pozwolą lepiej wyodrębnić populację osób starszych znacznie obciążonych, w tym z FS.

\section{Podsumowanie}

Nie istnieje w pełni skuteczna metoda zapobiegania i leczenia FS. Nie wykazano, by jakiekolwiek interwencje farmakologiczne przyczyniły się do poprawy sprawności chorych z FS. Aktywność fizyczna jest jedynym sposobem zapobiegającym utracie masy mięśniowej. Prawidłowe żywienie, uzupełniające niedobory kaloryczne oraz makroi mikroelementy, wczesne wykrywanie i leczenie ostrych schorzeń oraz współistniejących chorób przewlekłych, unikanie polipragmazji, ocena funkcji poznawczych i nastroju, wsparcie psychospołeczne, wczesne uruchamianie i zapobieganie upadkom stanowią podstawę postępowania u pacjentów z FS.

Równolegle, poza FS, chorzy w podeszłym wieku są obciążeni licznymi chorobami współistniejącymi, między innymi sercowo-naczyniowymi. Niejednokrotnie, mimo współistniejącej kruchości, największe korzyści w tej grupie pacjentów przynosi leczenie zabiegowe. Odpowiednia diagnostyka w kierunku wykrywania FS u osób starszych jest niezbędna do stratyfikacji ryzyka i podejmowania najkorzystniejszych dla danego chorego decyzji terapeutycznych. Skale służące do oceny FS stanowią cenne uzupełnienie skal do określania ryzyka sercowo-naczyniowego u osób w podeszłym wieku.

Pacjent z FS wymaga podejścia wielodyscyplinarnego. Leczenie takiego chorego nie ogranicza się jedynie do wykonania zabiegu. Niezbędna jest zarówno opieka przed-, jak i pooperacyjna, która powinna obejmować rehabilitację, odpowiednie żywienie oraz opiekę psychologa. Niezbędne są również dalsze badania w celu opracowania globalnej, łatwo dostępnej, wystandaryzowanej metody oceny FS, tak powszechnego w dzisiejszej populacji osób starszych.

\section{Konflikt interesów}

Autorzy deklarują brak konfliktu interesów. 


\section{Abstract}

Frailty syndrome (FS) is a common problem among elderly, which strongly affects poor patients' prognosis. Despite increasing interest there are no standardized methods allowing to identify patients with FS. Cardiovascular diseases are prevalent issues among people over 65 -years-old. Due to dynamic development of medicine often enough the greatest therapeutic advantages in elderly can be achieved using invasive cardiology procedures and open-heart surgeries. Condition for that kind of treatment is an accurate stratification of a risk related to invasive procedure. Most risk assessment scale used in cardiology are based on the patient's chronological age. The diagnosis of FS allows to evaluate the biological age of a patient, therefore provides valuable addition to commonly used methods of risk stratification related to invasive procedures among elderly.

This paper discusses the definitions of FS, most often used research tools to identify it and findings from selected studies of frailty among patients undergoing invasive cardiology procedures and open-heart surgeries.

Key words: frailty syndrome, elderly, cardiovascular disease, invasive cardiology procedure, open-heart surgery

Folia Cardiologica 2017; 12, 6: 563-564

\section{Piśmiennictwo}

1. Fried LP, Tangen CM, Walston J, et al. Cardiovascular Health Study Collaborative Research Group. Frailty in older adults: evidence for a phenotype. J Gerontol A Biol Sci Med Sci. 2001; 56(3): M146-M156, doi: 10.1093/gerona/56.3.m146, indexed in Pubmed: 11253156.

2. Fried LP, Walston J. Frailty and failure to thrive. In: Hazzard W, Blass JP, Halter JB. ed. Principles of geriatric medicine and gerontology. Ed 5. McGraw-Hill, New York 2003: 1487-1502.

3. Orme JG, Reis J, Herz EJ. Factorial and discriminant validity of the Center for Epidemiological Studies Depression (CES-D) Scale. J Clin Psychol. 1986; 42(1): 28-33, doi: 10.1002/1097-4679(198601)42:1<28::aidjclp2270420104>3.0.co;2-t, indexed in Pubmed: 3950011.

4. Taylor HL, Jacobs DR, Schucker B, et al. A questionnaire for the assessment of leisure time physical activities. J Chronic Dis. 1978; 31(12): 741-755, indexed in Pubmed: 748370.

5. Leng S, Chaves P, Koenig K, et al. Serum interleukin-6 and hemoglobin as physiological correlates in the geriatric syndrome of frailty: a pilot study. J Am Geriatr Soc. 2002; 50(7): 1268-1271, doi: 10.1046/j.1532-5415.2002.50315.x, indexed in Pubmed: 12133023.

6. Studenski S, Hayes RP, Leibowitz RQ, et al. Clinical Global Impression of Change in Physical Frailty: development of a measure based on clinical judgment. J Am Geriatr Soc. 2004; 52(9): 1560-1566, doi: 10.1111/j.1532-5415.2004.52423.x, indexed in Pubmed: 15341562.

7. Rockwood K, Song X, Macknight C, et al. A global clinical measure of fitness and frailty in elderly people. CMA. 2005; 173(5): 489-495, doi: 10.1503/cmaj.050051, indexed in Pubmed: 16129869.

8. Rockwood K, Hogan D, MacKnight C. Conceptualisation and measurement of frailty in elderly people. Drugs Aging. 2000; 17(4): 295-302, doi: 10.2165/00002512-200017040-00005, indexed in Pubmed: 11087007 .

9. Abellan van Kan G, Rolland YM, Morley JE, et al. Frailty: toward a clinical definition. J Am Med Dir Assoc. 2008; 9(2): 71-72, doi: 10.1016/j. jamda.2007.11.005, indexed in Pubmed: 18261696.

10. Chodzko-Zajko WJ, Proctor DN, Fiatarone Singh MA, et al. American College of Sports Medicine. American College of Sports Medicine position stand. Exercise and physical activity for older adults. Med Sci
Sports Exerc. 2009; 41(7): 1510-1530, doi: 10.1249/MSS.0b013e3181a0c95c, indexed in Pubmed: 19516148.

11. Gobbens RJJ, van Assen MA, Luijkx KG, et al. The predictive validity of the Tilburg Frailty Indicator: disability, health care utilization, and quality of life in a population at risk. Gerontologist. 2012; 52(5): 619-631, doi: 10.1093/geront/gnr135, indexed in Pubmed: 22217462.

12. Goldfarb M, Sheppard R, Afilalo J. Prognostic and therapeutic implications of frailty in older adults with heart failure. Curr Cardiol Rep. 2015; 17(11): 92, doi: 10.1007/s11886-015-0651-3, indexed in Pubmed: 26346250.

13. Leng S, Cappola A, Andersen R, et al. Serum levels of insulin-like growth factor-I (IGF-I) and dehydroepiandrosterone sulfate (DHEA-S), and their relationships with serum interleukin-6, in the geriatric syndrome of frailty. Aging Clin Exp Res. 2013; 16(2): 153-157, doi: $10.1007 /$ bf03324545.

14. Sokołowski R, Ciesielska N, Czajkowska A, et al. Patogeneza zespołu kruchości. J Health Sciences. 2014; 4(9): 197-204.

15. Uchmanowicz I, Lisiak M, Wontor R, et al. Frailty syndrome in cardiovascular disease: clinical significance and research tools. Eur J Cardiovasc Nurs. 2015; 14(4): 303-309, doi: 10.1177/1474515114568059, indexed in Pubmed: 25595359.

16. Newman AB, Gottdiener JS, Mcburnie MA, et al. Cardiovascular Health Study Research Group. Associations of subclinical cardiovascular disease with frailty. J Gerontol A Biol Sci Med Sci. 2001; 56(3): M158-M166, indexed in Pubmed: 11253157.

17. Cacciatore F, Abete $P$, Mazzella F, et al. Frailty predicts long-term mortality in elderly subjects with chronic heart failure. Eur J Clin Invest. 2005; 35(12): 723-730, doi: 10.1111/j.1365-2362.2005.01572.x, indexed in Pubmed: 16313247.

18. Walston J, McBurnie MA, Newman A, et al. Cardiovascular Health Study. Frailty and activation of the inflammation and coagulation systems with and without clinical comorbidities: results from the Cardiovascular Health Study. Arch Intern Med. 2002; 162(20): 2333-2341, doi: 10.1001/archinte.162.20.2333, indexed in Pubmed: 12418947.

19. Woods NF, LaCroix AZ, Gray SL, et al. Women's Health Initiative. Frailty: emergence and consequences in women aged 65 and older in the 
Women's Health Initiative Observational Study. J Am Geriatr Soc. 2005; 53(8): 1321-1330, doi: 10.1111/j.1532-5415.2005.53405.x, indexed in Pubmed: 16078957.

20. Afilalo J, Alexander KP, Mack MJ, et al. Frailty assessment in the cardiovascular care of older adults. J Am Coll Cardiol. 2014; 63(8): 747-762, doi: 10.1016/j.jacc.2013.09.070, indexed in Pubmed: 24291279.

21. Conroy RM, Pyörälä K, Fitzgerald AP, et al. SCORE project group. Estimation of ten-year risk of fatal cardiovascular disease in Europe: the SCORE project. Eur Heart J. 2003; 24(11): 987-1003, doi: 10.1016/ /s0195-668x(03)00114-3, indexed in Pubmed: 12788299.

22. D'Agostino RB, Vasan RS, Pencina MJ, et al. General cardiovascular risk profile for use in primary care: the Framingham Heart Study. Circulation. 2008; 117(6): 743-753, doi: 10.1161/CIRCULATIONAHA. 107.699579, indexed in Pubmed: 18212285.

23. Roques F, Nashef SA, Michel P, et al. European system for cardiac operative risk evaluation (EuroSCORE). Eur J Cardiothorac Surg. 1999; 16(1): 9-13, doi: 10.1016/s1010-7940(99)00134-7, indexed in Pubmed: 10456395.

24. Fox KAA, Dabbous OH, Goldberg RJ, et al. Prediction of risk of death and myocardial infarction in the six months after presentation with acute coronary syndrome: prospective multinational observational study (GRACE). BMJ. 2006; 333(7578): 1091, doi: 10.1136/bmj. 38985.646481.55, indexed in Pubmed: 17032691.

25. Pisters R, Lane DA, Nieuwlaat R, et al. A novel user-friendly score (HAS-BLED) to assess 1-year risk of major bleeding in patients with atrial fibrillation: the Euro Heart Survey. Chest. 2010; 138(5): 1093-1100, doi: 10.1378/chest.10-0134, indexed in Pubmed: 20299623.

26. Avezum A, Makdisse M, Spencer F, et al. GRACE Investigators. Impact of age on management and outcome of acute coronary syndrome: observations from the Global Registry of Acute Coronary Events (GRACE). Am Heart J. 2005; 149(1): 67-73, doi: 10.1016/j.ahj.2004.06.003, indexed in Pubmed: 15660036.

27. Topol EJ, Califf RM, Van de Werf F, et al. Perspectives on large-scale cardiovascular clinical trials for the new millennium. The Virtual Coordinating Center for Global Collaborative Cardiovascular Research (VIGOUR) Group. Circulation. 1997; 95(4): 1072-1082, doi: 10.1161/01. cir.95.4.1072, indexed in Pubmed: 9054772.

28. Ekerstad N, Swahn E, Janzon M, et al. Frailty is independently associated with short-term outcomes for elderly patients with non-ST-segment elevation myocardial infarction. Circulation. 2011; 124(22): 2397-2404, doi: 10.1161/CIRCULATIONAHA.111.025452, indexed in Pubmed: 22064593.

29. Huber $\mathrm{CH}$, Goeber V, Berdat $\mathrm{P}$, et al. Benefits of cardiac surgery in octogenarians - a postoperative quality of life assessment. Eur
J Cardiothorac Surg. 2007; 31(6): 1099-1105, doi: 10.1016/j. ejcts.2007.01.055, indexed in Pubmed: 17369044.

30. Lee DH, Buth KJ, Martin BJ, et al. Frail patients are at increased risk for mortality and prolonged institutional care after cardiac surgery. Circulation. 2010; 121(8): 973-978, doi: 10.1161/CIRCULATIONAHA. 108.841437, indexed in Pubmed: 20159833.

31. Sündermann S, Dademasch A, Rastan A, et al. Comprehensive assessment of frailty for elderly high-risk patients undergoing cardiac surgery. Eur J Cardiothorac Surg. 2011; 39(1): 33-37, doi: 10.1016/j. ejcts.2010.04.013, indexed in Pubmed: 20627611.

32. Sündermann S, Dademasch A, Rastan A, et al. One-year follow-up of patients undergoing elective cardiac surgery assessed with the Comprehensive Assessment of Frailty test and its simplified form. Interact Cardiovasc Thorac Surg. 2011; 13(2): 119-23; discussion 123 , doi: 10.1510/icvts.2010.251884, indexed in Pubmed: 21378017.

33. Afilalo J, Eisenberg MJ, Morin JF, et al. Gait speed as an incremental predictor of mortality and major morbidity in elderly patients undergoing cardiac surgery. J Am Coll Cardiol. 2010; 56(20): 1668-1676, doi: 10.1016/j.jacc.2010.06.039, indexed in Pubmed: 21050978.

34. Afilalo J, Mottillo S, Eisenberg MJ, et al. Addition of frailty and disability to cardiac surgery risk scores identifies elderly patients at high risk of mortality or major morbidity. Circ Cardiovasc Qual Outcomes. 2012; 5(2): 222-228, doi: 10.1161/CIRCOUTCOMES.111.963157, indexed in Pubmed: 22396586.

35. Green P, Cohen DJ, Généreux P, et al. Relation between six-minute walk test performance and outcomes after transcatheter aortic valve implantation (from the PARTNER trial). Am J Cardiol. 2013; 112(5): 700-706, doi: 10.1016/j.amjcard.2013.04.046, indexed in Pubmed: 23725996.

36. Green P, Arnold SV, Cohen DJ, et al. Relation of frailty to outcomes after transcatheter aortic valve replacement (from the PARTNER trial). Am J Cardiol. 2015; 116(2): 264-269, doi: 10.1016/j.amjcard.2015.03.061, indexed in Pubmed: 25963221.

37. Puls M, Sobisiak B, Bleckmann A, et al. Impact of frailty on shortand long-term morbidity and mortality after transcatheter aortic valve implantation: risk assessment by Katz Index of activities of daily living. Eurolntervention. 2014; 10(5): 609-619, doi: 10.4244/ /EIJY14M08_03, indexed in Pubmed: 25136880.

38. Stortecky S, Schoenenberger AW, Moser A, et al. Evaluation of multidimensional geriatric assessment as a predictor of mortality and cardiovascular events after transcatheter aortic valve implantation. JACC Cardiovasc Interv. 2012; 5(5): 489-496, doi: 10.1016/j. jcin.2012.02.012, indexed in Pubmed: 22625186. 